\title{
Т.С. ДВІРНА
}

Інститут ботаніки імені М.Г. Холодного НАН України

вул. Терещенківська, 2, м. Київ, 01601, Україна

dvirna_t@rambler.ru

\section{НОВЕ МІСЦЕЗНАХОДЖЕННЯ ЕСНINOCHLOA MICROSTACHYA (WIEGAND) RYDB. (POACEAE) НА ТЕРИTOРIÏ УКРАÏНИ}

Ключові слова: Echinochloa microstachya, адвентивний вид, кенофіт, Україна

Echinochloa microstachya (Wiegand) Rydb. (Poaceae) відомий з декількох місцезнаходжень на території України. Вперше вид виявив С.Л. Мосякін у м. Києві 1989 р.: велика колонія була відзначена в околицях Дарницького залізничного вузла, від східної межі станції «Дарниця» до станції «Депо», а невелику колонію зафіксовано поблизу залізничної станції «Петрівка» $[2,13]$. Ще один локалітет знайдено В.К. Тохтарем у 1993 р. на території Оленівського комбінату хлібопродуктів, біля рейок, одиничний екземпляр (Донецька обл.) [4].

Під час польових досліджень, проведених 2012 p. на території Роменсько-Полтавського геоботанічного округу, в південній частині Сумської обл. в м. Ромни (рис. 1) зафіксовано нове для регіону та України місцезнаходження E. microstachya; виявлено одиничний екземпляр рослини, що перебувала у фенофазі плодоношення, на залізничній станції в м. Ромни на піщано-щебеневому грунті (15.08. 2012, Т.С. Двірна; № 00104048, $K W$; рис. 2).

Вид поліморфний, E. microstachya [16] різні дослідники розглядали як Panicum crusgalli L. var. mite Pursh, Echinochloa crusgalli (L.) P. Beauv. var. mitis (Pursh) Peterm., E. muricata (P. Beauv.) Fernald var. mic-

(C) Т.С. ДВІРНА, 2013 rostachya Wiegand, E. pungens Rydb. var. microstachya (Wiegand) Fernald et Griscom [2, 13]. За сучасними уявленнями, E. microstachya належить до північноамериканської за походженням групи E. muricata s.1., що представлена тетраплоїдними расами. Ocкільки ця група є таксономічно складною, вчені неодноразово стикалися з нечіткою відмінністю видів роду Echinochloa [11, 12]; вивчаючи гербарні матеріали Ботанічного інституту імені В.Л. Комарова Російської академії наук $(L E)$ С.Л. Мосякін перевизначив більшість північноамериканських зразків, визначених як E. crusgalli, серед яких переважали види групи E. muricata s.1. [2]; з такою ж проблемою зіткнулися і бельгійські ботаніки [9, 15]. Основні відмінності видів $[3,9,12,15]$ подано в таблиці.

Echinochloa microstachya - кенофіт північноамериканського походження. Рослини у природних умовах приурочені переважно до відкритих вологих (у тому числі алювіальних) і рудеральних місць $[5,8,17,20]$. У межах вторинного ареалу вид трапляється в Европі [1, 5, 9, 10, 18], Східній Азії $[2,19]$ та Австралії [14], де поширений здебільшого на сільськогосподарських угіддях, а в Україні та Росії зафіксований виключно поблизу залізниць $[2,4,13]$.

ISSN 0372-4123. Ukr. Botan. Journ., 2013, vol. 70, № 4 


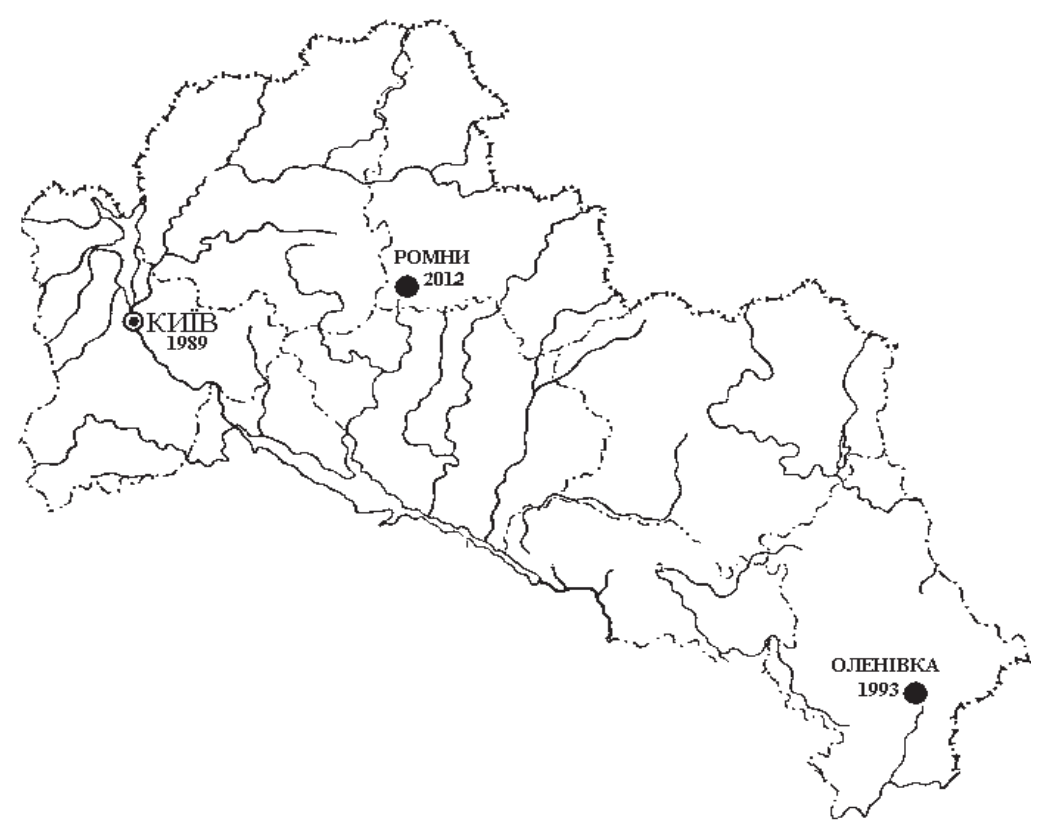

Рис. 1. Карта місцезнаходжень Echinochloa microstachya (Wiegand) Rydb. в $\mathbf{У}_{\mathrm{K}}$ раїні: а) в Києві відзначено С.Л. Мосякіним (1989); б) у Ромнах - автором (2012)

Fig. 1. Map of localities of Echinochloa microstachya (Wiegand) Rydb. in Ukraine: a) in Kiev by S. Mosyakin (1989); b) in Romny by the author (2012)

Рис. 2. Echinochloa microstachya (Wiegand) Rydb.

Fig. 2 Echinochloa microstachya (Wiegand) Rydb.

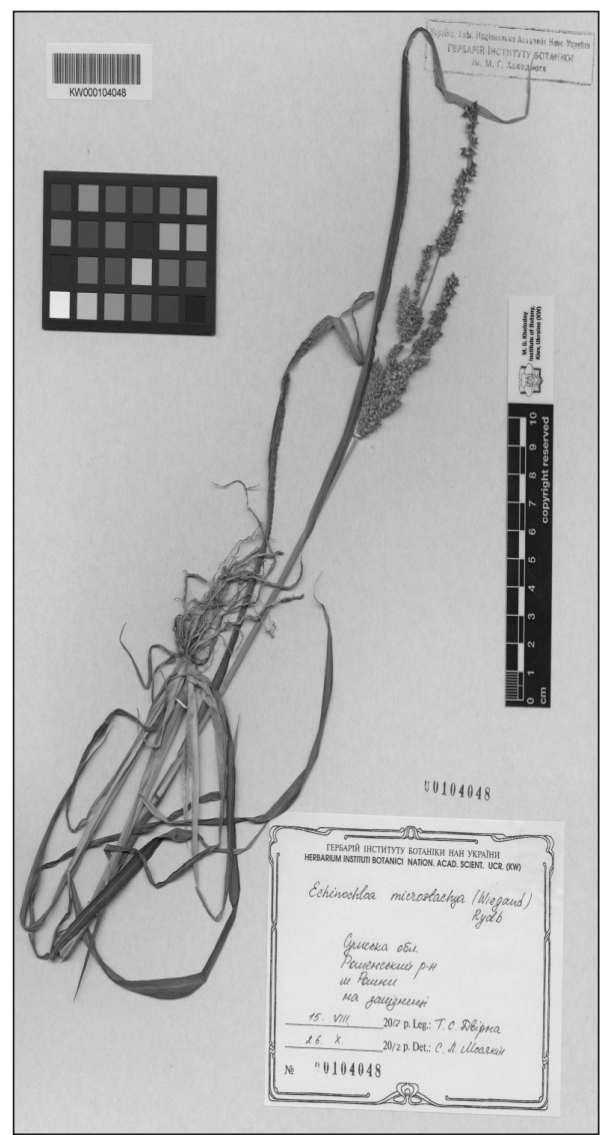

Основні відмінності $E$. microstachya, E. muricata та $E$. crusgalli

\begin{tabular}{|l|l|l|}
\hline \multicolumn{1}{|c|}{ E. microstachya } & \multicolumn{1}{|c|}{$\begin{array}{c}\text { E. muricata } \\
\text { E. crusgalli }\end{array}$} \\
\hline $\begin{array}{l}\text { Колоски від 2,5 до } 3,8 \text { мм завдовжки, } \\
\text { безості або з остю від 2,3 до 3,6 мм }\end{array}$ & $\begin{array}{l}\text { Колоски від } 3,5 \text { до } 5 \text { мм завдовжки, } \\
\text { ость 6-16 мм }\end{array}$ & $\begin{array}{l}\text { Колоски від 2,3 до 3,5 мм завдовжки, ость від } \\
2 \text { до } 5 \text { см }\end{array}$ \\
\hline $\begin{array}{l}\text { Нижні квіткові луски фертильної квітки на верхівці досить плавно перехо- } \\
\text { дять у відтягнутий носик. Носик при основі без дрібних шипиків, покри- } \\
\text { тий лише війками }\end{array}$ & $\begin{array}{l}\text { Хівці різко переходять у носик. Носик при ос- } \\
\text { нові з численними дрібними війками }\end{array}$ \\
\hline $\begin{array}{l}\text { Верхня колоскова луска і нижня квіткова луска стерильної квітки мають } \\
\text { міцні відігнуті шипуваті щетинки на розширених папілах }\end{array}$ & - \\
\hline
\end{tabular}

Імовірно, вид занесений в Україну разом із сільськогосподарськими культурами. Ми припускаємо, що подальше його поширення територією УКраїни не буде дуже активним, найімовірніше, це відбуватиметься залізничними шляхами.
Гербарний зразок виду передано до Гербарію Інституту ботаніки НАН України $(K W)$.

Автор висловлює щиру подяку чл.-кор. НАН Украӥни С.Л. Мосякіну за допомогу у визначенні гербарного зразка та надану літературу під час підготовки статті до друку. 


\section{СПИСОК ЛІТЕРАТУРИ}

1. Джус M.A. Новые адвентивные виды рода Ежовник (Echinochloa P. Beauv., Poaceae) во флоре Беларуси // Вестн. Беларус. ун-та. Сер. 2: Хим. Биол. Геогр. - 2012. - № 1. C. $58-62$.

2. Мосякин С.Л., Бочкин В.Д. Североамериканские адвентивные виды Echinochloa во флорах Украины и России // Бюл. Гл. бот. сада. - 1993. - Вып. 168. - С. 56-61.

3. Определитель высших растений Украины / Д.Н. Доброчаева, М.И. Котов, Ю.Д. Прокудин и др. - Киев: Наук. думка, 1987. - 548 с.

4. Tохтар В.К. Доповнення до адвентивної флори південного сходу України // Укр. ботан. журн. - 1996. - 53, № 6. - С. 687-690.

5. Banfi E., Galasso G. (eds.) La flora esotica lombarda. - Milano: Museo di Storia Naturale di Milano, 2010. - 273 p.

6. Barrett S.C.H., Wilson B.F. Colonizing ability in the Echinochloa crus-galli complex (barnyard grass). I. Variation in life history // Can. J. Bot. - 1981. - 59. - P. 1844-1860.

7. Darbyshire S.J. Inventory of Canadian Agricultural Weeds. Ottawa: Agriculture and Agri-Food Canada, Research Branch, 2003. - $401 \mathrm{p}$.

8. Dore W. G., McNeill J. The grasses of Ontario. - Ottawa: Canad. Departm. of Agriculture, 1980. - $566 \mathrm{p}$.

9. Hoste I. The naturalisation history of Echinochloa muricata in Belgium, with notes on its identity and morphological variation // Belg. J. Bot. - 2004. - 137(2). - P. 163.-174.

10. Kerguélen M. (coll. G. Bosc et J. Lambinon). Données taxonomiques, nomenclaturales of chrologiques pour une revision de la flore de France // Lejeunia. - 1987. - 120. - P. 264.

11. Michael P.W. Taxonomy and distribution of Echinochloa species with special reference to their occurence as weeds of rice // Weed Control in Rice (Proc. Conf. Manila, Philippines, 31 Augustus - 4 September 1981). - Intern. Rice Research Inst., 1983. - P. 291-306.

12. Michael P.W. Echinochloa P. Beauv. // Flora of North America Editorial Committee. (ed.), Flora of North America North of Mexico. - New York; Oxford: Univ. Press, 2003. - Vol. 25._P. 390-403.

13. Mosyakin S.L. Preliminary synopsis of the genus Echinochloa Beauv. (Poaceae: Paniceae) in the former USSR // Ботаника и микология на пути в третье тысячелетие: Междунар. сб. статей, посвящ. 70-летию акад. НАНУ К.М. Сытника / Отв. ред. С.П. Вассер. - Киев: Ин-т ботаники НАНУ, 1996. - C. $217-225$.

14. Randall R.P. The introduced flora of Australia and its weed status. - CRC for Australian Weed Management, 2007. $524 \mathrm{p}$.

15. Rombaut R. Stekelige hanenpoot (Echinochloa muricata): competitiviteit en reactie ten aanzien van herbiciden / Masterp- roef voorgedragen tot het behalen van de graad van Master in de bio-ingenieurswetenschappen: landbouwkunde - Univ. Gent, Faculteit Bio-ingenieurswetenschappen, Academiejaar 2010-2011. - Gent, 2011. - 90 p.

16. Rydberg P.A. Taxonomic notes on the flora of the prairies and plains of central North America // Brittonia. - 1931. - 1. P. 79-104.

17. Simmons R.H. Native vascular flora of the city of Alexandria, Virginia. - Richmond (Virginia): Virginia Departm. of Conservation and Recreation, Division of Natural Heritage, 2009. $48 \mathrm{p}$.

18. Verloove F. Catalogue of neophytes in Belgium (1800-2005) // Scripta Bot. Belgica. - 2006. - 39. - 89 p.

19. Yabuno T. Biosystematic study of the genus Echinochloa // Japan. J. Bot. - 1966. - 19. - P. 277-323.

20. Zieger S.R., Sohmer S.H. The flora of dredged material sites in navigation pool 8 of the upper Mississippi River. Final report. - La Crosse: Univ. of Wisconsin, 1977. - 103 p.

Рекомендує до друку

В. І. Бурда

Надійшла 23. 01. 2013 р.

\section{T.С. Двирна}

Институт ботаники имени Н.Г. Холодного НАН Украины, г. Киев

НОВОЕ МЕСТОНАХОЖДЕНИЕ ЕСНINOCНLOA

MICROSTACHYA (WIEGAND) RYDB. (POACEAE) НА ТЕРРИТОРИИ УКРАИНЫ

Приводятся сведения о новом локалитете для Роменско-Полтавского геоботанического округа, обнаруженном на железной дороге г. Ромны, и третьем для Украины, вида адвентивного растения E. microstachya.

Ключ че в е слов в: Echinochloa microstachya, адвентивный вид, кенофит, Украина.

\section{T.S. Dvirna}

M.G. Kholodny Institute of Botany, National Academy of Sciences of Ukraine, Kyiv

\section{A NEW FIND OF ECHINOCHLOA MICROSTACHYA (WIEGAND) RYDB. (POACEAE) IN UKRAINE}

Information about a new locality for the territory of the RomnyPoltava Geobotanical Region and for Ukraine of the alien species Echinochloa microstachya is provided (Romny, railways).

Ke y words: Echinochloa microstachya, alien species, kenophyte, Ukraine. 